\title{
The Role of Teacher Behavior, Motivation and Emotion in Predicting Academic Social Participation in Class
}

\author{
Javier Sánchez-Rosas*, Paula Belén Takaya**, Alicia Verónica Molinari***
}

Doctoral candidate in Psychology. Laboratory of Psychological and Educational Assessment, Faculty of Psychology, Universidad Nacional de Córdoba, Córdoba, Argentina. Correo electrónico: jsanchezrosas@psyche.unc.edu.ar

** Degree in Psychology. Laboratory of Psychological and Educational Assessment, Faculty of Psychology, Universidad Nacional de Córdoba, Córdoba, Argentina. Correo electrónico: paulatakaya@psyche.unc.edu.ar

*** Degree in Psychology. Laboratory of Psychological and Educational Assessment, Faculty of Psychology, Universidad Nacional de Córdoba, Córdoba, Argentina. Correo electrónico: amolinari.unc@gmail.com

Recibido: 14 de septiembre del 2015 Aprobado: 11 de marzo del 2016

Cómo citar este artículo: Sánchez-Rosas, J., Takaya, P. B., \& Molinari, A. V. (2016). The Role of Teacher Behavior, Motivation and Emotion in Predicting Academic Social Participation in Class. Pensando Psicología, 12(19), 39-53. doi: http://dx.doi.org/10.16925/ pe.v12i19.1327

\begin{abstract}
Introduction: Academic social participation addresses student engagement behaviors that involve social interactions with peers and teachers. Objective: Perceived teacher behavior, task value, academic self-efficacy, class enjoyment and shame's role in predicting academic social participation was analyzed. Method: Psychology students from a large national university completed self-report questionnaires assessing the model variables. A proposed model was evaluated by path analysis. Results: Model showed good fit to the data, explaining $31 \%$ of variance. Positive influences were detected of perceived teacher behavior on task value $(\beta=0.42)$, academic self-efficacy $(\beta=0.19)$, and class enjoyment $(\beta=0.24)$; of task value on class enjoyment $(\beta=0.52)$; and of class enjoyment on academic social participation $(\beta=0.44)$. Academic self-efficacy negatively affected class shame $(\beta=-0.38)$, while class shame $(\beta=-0.44)$ and task value $(\beta=-0.24)$ showed a negative influence on academic social participation. Conclusion: Utility of modifying teacher behavior and motivation as a means to affect emotion was demonstrated. Class enjoyment and shame were the stronger predictors of academic social participation. Individual variables' importance in moderating contextual influence on engagement was suggested.
\end{abstract}

Keywords: academic self-efficacy, academic social participation, achievement emotions, behavioral engagement, perceived teacher behavior, task value. 


\title{
El papel del comportamiento del profesor, la motivación y la emoción en la predicción de la participación social académica en clase
}

\begin{abstract}
Resumen
Introducción: la participación social académica aborda los comportamientos de participación estudiantil que implican interacciones sociales con compañeros y profesores. Objetivo: se analizó el papel del comportamiento percibido del profesor, el valor de la tarea, la autoeficacia académica, el disfrute y la vergüenza en clase en la predicción de la participación social académica. Método: los estudiantes de psicología de una importante universidad nacional completaron cuestionarios de autoinforme que evaluaban las variables del modelo. Se evaluó un modelo propuesto mediante el análisis de senderos. Resultados: el modelo mostró un buen ajuste a los datos, explicando el 31\% de la varianza. Se detectaron influencias positivas del comportamiento percibido del profesor en el valor de la tarea $(\beta=0,42)$, la autoeficacia académica $(\beta=0,19)$ y el disfrute de la clase $(\beta=0,24)$; del valor de la tarea en el disfrute de la clase $(\beta=0,52)$; y del disfrute de la clase en la participación social académica $(\beta=0,44)$. La autoeficacia académica afectó negativamente la vergüenza en clase $(\beta=-0,38)$, mientras que la vergüenza en clase $(\beta=-0,44)$ y el valor de la tarea $(\beta=-0,24)$ mostraron una influencia negativa en la participación social académica. Conclusión: se demostró la utilidad de modificar el comportamiento del profesor y la motivación como medio para afectar las emociones. El disfrute y la vergüenza en clase fueron los predictores más fuertes de la participación social académica. Se sugirió la importancia de las variables individuales en la moderación de la influencia contextual en la participación.
\end{abstract}

Palabras clave: autoeficacia académica, participación social académica, emociones de logro, compromiso comportamental, comportamiento percibido del profesor, valor de la tarea.

\section{O papel do comportamento do professor, da motivação e da emoção na predição da participação social acadêmica em aula}

\section{Resumo}

Introdução: a participação social acadêmica aborda os comportamentos de participação estudantil que implicam interações sociais com companheiros e professores. Objetivo: analisou-se o papel do comportamento percebido do professor, o valor da tarefa, a autoeficácia acadêmica, o disfrutar e a vergonha em aula na predição da participação social acadêmica. Método: os estudantes de psicologia de uma importante universidade nacional preencheram questionários de autorrelato que avaliavam as variáveis do modelo. Avaliou-se um modelo proposto mediante a análise de trajetórias. Resultados: o modelo mostrou um bom ajuste aos dados, explicando $31 \%$ da variância. Detectaram-se influências positivas do comportamento percebido do professor no valor da tarefa $(\beta=0,42)$, a autoeficácia acadêmica $(\beta=0,19)$ e o desfrutar da aula $(\beta=0,24)$; do valor da tarefa no desfrutar da aula $(\beta=0,52)$ e do desfrutar da aula na participação social acadêmica $(\beta=0,44)$. A autoeficácia acadêmica afetou negativamente a vergonha em aula $(\beta=-0,38)$, enquanto a vergonha em aula $(\beta=-0,44)$ e o valor da tarefa $(\beta=-0,24)$ mostraram uma influência negativa na participação social acadêmica. Conclusão: demonstrou-se a utilidade de modificar o comportamento do professor e a motivação como meio para afetar as emoções. O desfrutar da aula e a vergonha foram os preditores mais fortes da participação social acadêmica. Sugeriu-se a importância das variáveis individuais na moderação da influência contextual na participação.

Palavras-chave: autoeficácia acadêmica, participação social acadêmica, emoções de realização, compromisso comportamental, comportamento percebido do professor, valor da tarefa. 
In the educational context, engagement is increasingly attracting attention for its use to promote motivation and academic performance (Christenson, Reschly, \& Wylie, 2012; Fredricks, Blumenfeld, \& Paris, 2004; Schaufeli, Martínez, Marques-Pinto, Salanova, \& Bakker, 2002). In the university setting, classrooms provide a scenario where a set of behaviors related to class engagement can be observed, such as commenting on a topic being explained, asking questions or contributing in class discussions (Takaya, 2014). Engagement behaviors support the development of learning processes and promote favorable outcomes in academic activities. Emotions, along with some of its contextual and individual backgrounds, would be able to influence students' behavioral engagement, and in particular, class participation (Patrick, Ryan, \& Kaplan, 2007; SánchezRosas, 2013; Takaya, 2014). For this reason, in this study the role of perceived teacher behavior, task value, academic self-efficacy, class enjoyment and shame in predicting academic social participation of Argentine university students is evaluated.

\section{Academic social participation}

This study is in line with research on achievement motivation and emotion addressing student engagement (Bandura, 1997; Eccles, 2005; Fredricks et al., 2004; Liem, Lau, \& Nie, 2008; Pekrun, 2006). Student engagement is a multidimensional construct, which includes cognitive, emotional and behavioral engagement (Fredricks et al., 2004). As noted by Liem et al. (2008), behavioral engagement is often treated as continuous effort, determination and perseverance of students in learning. Therefore, behavioral engagement is related to persistence (Elliot \& Dweck, 1988), and effort regulation (Pintrich, Smith, García, \& McKeachie, 1993) to cope with obstacles in learning. By defining behavioral engagement in this way, behaviors such as academic social participation are not taken into account.

In this study, through the construct of academic social participation, a set of behaviors of student engagement in class will be addressed that share the characteristic of involving social interactions with peers and teachers.

Overall, different works consider this type of behavior within broader behavioral repertoires. For example, Fredericks et al. (2004) include behaviors of academic social participation (e.g., contributing to discussions, and asking questions) within a dimension of behavioral engagement related to students' involvement in learning, along with other behaviors such as attention, perseverance, concentration and effort. Azevedo, di Sessa, and Sherin (2012), define student engagement as intensity and quality of class participation, including behaviors such as participation in class discussions. At the same time, Green et al. (2012) define class participation as a dimension within behavioral engagement, characterizing it as active involvement in class.

More specific studies present, for example, social participation within the context of learning in small groups. That is the case for Linnenbrink-Garcia, Rogat and Koskey (2011), as they state the construct of social-behavioral engagement, including social interactions that support learning in small groups. Meanwhile, Hijzen, Boekaerts and Vedder (2007), worked on socially oriented task behavior as a type of student engagement in cooperative learning.

For this study, academic social participation is defined as student's behavior of social interaction with peers and teachers in class with academic purposes, that is, social behavior meant to regulate their learning processes. This behavior implies verbal exchanges like asking questions to the teacher, discussing in class with teacher and peers, or giving one's viewpoint about material being explained.

\section{Control-value theory of achievement emotions}

In experimental research, mood and emotions have been found to influence a wide range of cognitive processes, including attention, memory storage and retrieval, social judgment, decision making, convergent problem solving, and creative thinking (Lewis \& Haviland-Jones, 2000). Emotions can also affect the motivational processes and choice of different behavioral repertoires in education, for example with regard to selection of learning strategies and student preference for internal or external regulation of behavior (Pekrun et al., 2007).

One of the most promising models in identifying antecedents, presence, and effects of emotions in academic contexts is the control-value theory of achievement emotions by Pekrun (2006). The main premise of this theory states that appraisals of activities and their past and future results are essential for arousal of achievement emotions. Pekrun defines achievement emotions as directly related to learning activities and the outcomes of those activities. These 
emotions arise when students perceive themselves in control, or out of control, of learning activities and eventual outcomes that are subjectively important to them. This means that students' control-related and value-related appraisals are assumed to be the most important proximal determinants of their achievement emotions (Pekrun et al., 2007).

Control appraisals pertain to perceived controllability of achievement-related actions and outcomes, which are often conceptualized in the research literature as academic self-efficacy (Bandura, 1977). Value appraisals relate to subjective importance of achievement activities and their outcomes, commonly identified as task value (Eccles, 2005). Finally, this theory states that context can indirectly affect emotions by influencing control and value appraisals.

Contextual facets considered important include: 1) task's cognitive quality and instruction characteristics, 2) induction of appraisals, 3) autonomy support, 4) expectancies and goals framework, and 5) achievement feedback and its consequences (Pekrun, 2006).

Emotions experienced in classrooms are mostly influenced by how students perceive what happens in class. Considering this, relations among perceived teacher behavior, task value, self-efficacy, class enjoyment, class shame and academic social participation are reviewed below, and an explicative model of academic social participation is hypothesized.

\section{Perceived teacher behavior and motivational variables: task value and academic self-efficacy}

Following control-value theory assumptions, social environments have an influence on achievement emotions, which is mediated by control-value appraisals (Pekrun, 2006). In the classroom, students can find resources and support to their learning processes (Guthrie, Wigfield, \& You, 2012; Patrick, Ryan, \& Kaplan, 2007). At the same time, they can perceive threats and difficulties, as it would be the chance of being exposed, or failing in an academic task (Sánchez-Rosas, Becco, \& Marquez, 2011).

Students' perception of teacher behavior is a key indicator of the classroom social environment. Perceived teacher behavior relates to the way teachers present their subjects; lesson's characteristics; and teacher's behaviors that encourage student participation and active engagement in learning processes (Takaya, 2014). Perceived teacher behavior is posited to affect motivational variables such as task value and self-efficacy, which in turn are assumed to have a role in explaining achievement emotions and academic social participation.

Task value relates to the extent to which learning contents and materials are perceived by students as important, useful and interesting (Pintrich et al., 1993). Wigfield and Eccles (2000) define task value as the incentive that leads students to engage in academic tasks. These task characteristics make it more or less likely for the individuals to get involved (Eccles, 1987; Eccles et al., 1983; Wigfield \& Eccles, 1992).

On the other hand, self-efficacy refers to "belief in one's capabilities to organize and execute the courses of action required to produce given attainments" (Bandura, 1997, p. 3). Self-efficacy beliefs affect people's choices over behaviors and attitudes, as people generally avoid tasks and situations they believe exceed their capabilities, while they begin and develop tasks in which they feel competent and confident (Bandura, 1986). Moreover, self-efficacy affects the levels of effort and persistence a person uses in meeting a task's demands and succeeding in it.

From extant research, it is assumed that students' perception of positive behavior from their teachers relates to higher levels in task value and self-efficacy.

Students are more likely to positively value class activities and experience positive feelings in classrooms when teachers communicate clear and reasonable expectations, provide instrumental help and support students' autonomy (Assor, Kaplan, \& Roth, 2002; Grolnick, Ryan, \& Deci, 1991). Furthermore, when teachers create opportunities for students to engage in a variety of school activities, these experiences provide students with information regarding their capabilities, allowing them to explore their interactions with other people and their own autonomy (Wang \& Eccles, 2013). In this way, processes are initiated that allow for the development of students' self-concept regarding their skills and capacities, promoting self-efficacy.

About this topic, Smart (2014) stated that high quality teacher-student interactions (i.e., rich communication; consistent, stable, respectful, and fair interactions; and emotional support) contributed to students' self-efficacy and value in learning sciences. Conversely, students' perception of oppositional teacher behavior of dissatisfaction diminished student self-efficacy for learning science. Federici and Skaalvik (2014) found that teacher instrumental support was positively and directly related to utility value, intrinsic 
value and students' effort in math. Also in Velez and Cano's study (2012), teacher verbal and nonverbal immediacy showed moderate to low correlations with students' task value and self-efficacy.

From a broader viewpoint, Ahmed, Minnaert, Van der Werf and Kyuperet (2010) found that perceived teacher support promoted students' motivational beliefs and emotions in mathematics, which in turn improved their performance. They suggested that by relying on teacher support, students felt safe in class, increasing their confidence in their skills to successfully fulfill assigned tasks.

\section{Motivational variables and achievement emotions: class enjoyment and shame}

Achievement emotions are defined as emotions tied directly to achievement activities or achievement outcomes, like attending class or obtaining an exam's scores (Pekrun et al., 2007). Control-value theory of emotions posits that control and value appraisals are the most proximal determinants of student achievement emotions (Pekrun, 2006). Examples of these appraisals are the student's judgment about his or her capability to carry out an assigned task, and the value that students attach to the task itself or to the task as a means to attain some benefit. As different emotions focus in different objects and encompass distinct temporal frames, control and value appraisals play diverse roles depending on the emotion they produce (Pekrun, 2006).

In this study, relations between two motivational variables, self-efficacy and task value; and two achievement emotions, class enjoyment and shame; will be addressed.

Enjoyment is a positive activating emotion that arises when an activity is viewed as being controllable and valued positively (Ainley \& Ainley, 2011; Goetz, Frenzel, Hall, \& Pekrun, 2008; Goetz, Hall, Frenzel, \& Pekrun, 2006). Therefore, positive control and value appraisals instigate enjoyment, which in turn (and like other positive emotions) has positive influence on learning, activation of cognitive resources, performance and use of learning strategies (Ashby, Isen, \& Turken, 1999; Pekrun, 2006; Pekrun, Goetz, Titz, \& Perry, 2002). Self-efficacy and task value are considered important predictors of enjoyment (Pekrun, 2006; Pekrun, Goetz, Frenzel, Barchfeld, \& Perry, 2011), as they reflect control over, and attribution of positive characteristics to activities.
Shame is a negative activating retrospective emotion that arises after obtaining a negative outcome in class (Pekrun, 2006); typically related to worries about showing one's incompetence in front of others (Sánchez-Rosas \& Pérez, 2015). Negative control and value appraisals arouse shame, which at the same time affects cognitive resources, use of learning strategies, self-regulation and performance (Pekrun, 2006). In this respect, shame arises in the context of self-attribution of negative outcomes that are perceived as aversive (Pekrun, 2007). Therefore, as they refer to beliefs about the student's own ability and subjective judgments about tasks and outcomes; self-efficacy and task value constructs have a negative impact on shame (Pekrun et al., 2011).

Research has consistently documented direct and mediated links from academic self-efficacy (Pekrun et al., 2004, 2011; Pekrun, Elliot, \& Maier, 2006, 2009) and academic social self-efficacy (Sánchez-Rosas, n.d.; Sánchez-Rosas \& Pérez, 2015) to enjoyment and shame. This means that confidence about adequately performing in subjects (Pintrich et al., 1993) and confidence about carrying out social behavior needed to perform well (Solberg, O’Brien, Villareal, Kennel, \& Davis, 1993) would decrease shame while increasing enjoyment experienced by students. Putwain, Sander and Larkin (2013) posit that a high level of self-efficacy establishes a sense of control through beliefs that positive outcomes are achievable. Therefore challenge, rather than threat, appraisals and subsequent pleasant (e.g., enjoyment) rather than unpleasant emotions (e.g., anxiety) are aroused.

Furthermore, other studies found evidence supporting connections between task value, and enjoyment and shame in different academic situations (Ainley \& Ainley, 2011; Noteborn, Bohle Carbonell, Dailey-Herbert, \& Gijselaers, 2012; Pekrun et al., 2011; Sánchez-Rosas, n.d.; Sánchez-Rosas \& Pérez, 2015). Specifically, task value shows a weak negative correlation with shame, and a high positive one with enjoyment. Therefore, importance, utility and interest perceptions about class activities and contents have a strong influence over enjoyment arousal, but not over shame. As Pekrun (2006) states, enjoyment is an emotion that arises during tasks, unlike shame, that arises after obtaining negative outcomes. Task value guides attention toward diverse perceptions regarding on-going activities, and is therefore more strongly connected to enjoyment of achievement activities. 


\section{Enjoyment, shame, and academic social participation}

At present, there is a dearth of research about emotions' effects on social participation in class, as this construct has not been studied in a unified way. There is, however, evidence regarding emotion and mood influences on student engagement as a general construct. As Pekrun (2006) asserts, positive emotions exert an effect on engagement related constructs, like students' self-regulation of learning. King et al. (2015) found that students who were in a positive affective state were also more likely to report higher levels of engagement, while those in a negative affective state were more likely to report lower levels of engagement. They pointed out that positive emotions, by allowing positive mood, foster approach oriented behavior, making it easier for students to address new goals and progressively build up skills and learning resources over time. Otherwise, negative mood would direct students to engage in rigid behavioral repertoires, inhibit approach-oriented motivation, and decrease their cognitive flexibility, which could lead to disaffection.

Pekrun and Linnenbrink-Garcia (2012) suggest that positive activating emotions as learning enjoyment are positively related to effort, while negative activating emotions as shame show a negative relation with effort. Ainley and Ainley (2011) found that enjoyment in learning sciences positively predicted students' interest in finding out more about topics they had been working on, suggesting engagement would be fostered by enjoyment of academic tasks. Additionally, class enjoyment showed positive relations with confidence about performing social behaviors in academic settings, and with students' attitudes about asking questions in class (SánchezRosas, 2013).

On the other hand, class shame has presented a negative effect on some forms of academic social participation, such as class participation (Sánchez-Rosas et al., 2011) and academic help seeking (Sánchez-Rosas, 2013; Sánchez-Rosas \& Pérez, 2015). Therefore, following extant research, a negative relationship between class shame and academic social participation, and a positive relationship between class enjoyment and academic social participation are expectable.

Building from the literature reviewed, it is apparent that both contextual and individual variables are instrumental in effectively explaining individual differences in academic social participation. For this study, it was decided to analyze effects and explanatory contribution of perceived teacher behavior, task value, self-efficacy, and class enjoyment and shame on academic social participation.

\section{Hypothesized model}

Figure 1 displays a theoretical model depicting the proposed relationships among perceived teacher behavior, task value, self-efficacy, enjoyment and shame.

Based on the literature reviewed, we expect to find: 1) a positive effect of perceived teacher behavior on task value and self-efficacy; 2) a positive effect of task value and self-efficacy on class enjoyment and a negative effect on class shame; and 3) a positive effect of class enjoyment on academic social participation and a negative effect of class shame on academic social participation.

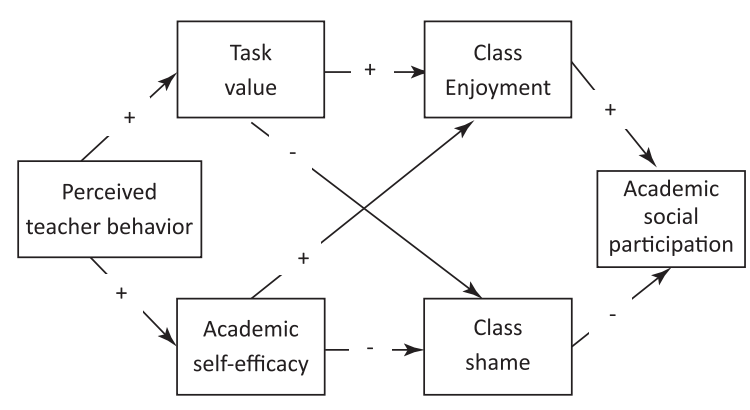

Figure 1. Hypothesized model of academic social participation. Compiled by the authors.

\section{Method}

\section{Participants}

The sample was a self-selected volunteer population, as participants decided whether or not to participate in the study (Sterba \& Foster, 2008). One hundred eighty five ( $85 \%$ female; $\mathrm{M}=22.94$ years, $\mathrm{SD}=3.11$ ) Argentinean undergraduates pursuing studies of psychology at a large national university participated in the study. Gender distribution represents the habitual distribution in the sampled department. The classes of Clinical Psychology course were chosen for its relevance to career development in psychology students, the reduced number of students, and the 
opportunities for participation and personalized interaction between teacher and students.

\section{Measures}

\section{Perceived teacher behavior}

The student's perceptions of teacher behavior in class were assessed. The utilized scale consists of thirteen items about behaviors of enthusiasm, interaction with students, content delivery, among other positive behaviors (e.g., Teacher promotes participation during class). Students rated teacher behavior occurrence on a five point Likert-type scale from 1 (never) to 5 (always). This scale proved adequate internal consistency and test-criterion validity (Takaya \& SánchezRosas, 2014). In the present study, unidimensionality and internal consistency were tested, and acceptable results were obtained ( $\mathrm{KMO}=0.82,47 \%$ variance accounted, and factor loading $>0.50$ ).

\section{Task value}

The unidimensional task value scale by Pintrich et al. (1993) was used, that evaluates perceived interest, importance and utility regarding learning materials and contents, and consists of six items (e.g., I think what I learn in this course will be useful in others, original $\alpha=0.90$ ). The items were answered using a Likert scale, expressing the degree of agreement, from 1 (strongly disagree) to 5 (strongly agree). This scale demonstrated criterion validity regarding achievement emotions, in a sample of university students from the same population (Sánchez-Rosas, Piotti, Sánchez, Pereira, \& Debat, 2011). Unidimensionality and internal consistency yielded acceptable results in this study $\left[\chi^{2}(8, N=185)=12.27, p=0.14, \chi^{2} / \mathrm{df}=1.53\right.$, $\mathrm{CFI}=0.97, \mathrm{GFI}=0.93, \mathrm{RMSEA}=0.072]$.

\section{Academic self-efficacy}

The Academic self-efficacy scale by Pintrich et al. (1993) was used, that assesses student's beliefs about their abilities to perform the tasks required in this area. It includes seven items (e.g., I can understand the most complex concepts in this course) and the original internal consistency is good $(\alpha=0.90)$. Participants respond on a 1 (I can't do it) to 10 (totally sure I can do it) scale, expressing their confidence in succeeding at each behavior. Unidimensionality and internal consistency were tested using confirmatory factor analysis, and optimal results were obtained $\left[\chi^{2}\right.$ $(14, N=185)=25.41, p=0.03, \chi^{2} / \mathrm{df}=1.81, \mathrm{CFI}=0.99$, GFI $=0.97$, RMSEA $=0.067]$.

\section{Enjoyment and shame in class}

A modified version of the Achievement Emotions Questionnaire's (Pekrun et al., 2011), adapted to Spanish by Sánchez-Rosas (n.d.) was used, that assesses enjoyment and shame when attending class. On one hand, class-related enjoyment was tested through a ten items scale (e.g., Enjoying this class makes me want to participate). Unidimensionality and internal consistency were tested, and acceptable results were obtained $\left[\chi^{2}(27, N=185)=50.59, p=.01, \chi^{2} / \mathrm{df}=1.87\right.$, CFI $=0.97$, GFI $=0.95$, RMSEA $=0.069]$. On the other hand, class-related shame was tested through an eleven-item scale (e.g., When I say anything in class, I feel like I am making a fool of myself). Unidimensionality and internal consistency were tested, with optimal results $\left[\chi^{2}(38, N=185)=75.67, p=0.001, \chi^{2} / \mathrm{df}=\right.$ 1.99$, CFI $=0.96$, GFI $=0.93$, RMSEA $=0.073]$. Students rated their emotional experiences of class enjoyment and shame on a five point Likert-type scale from 1 (never) to 5 (always).

\section{Academic social participation}

A three-item scale that assesses academic social participation was used (e.g., Express an opinion on a topic that is being explained, Actively participate in class discussions, Ask the teacher questions to understand better). Students rate the behavior occurrence on a five point Likert-type scale from 1 (never) to 5 (always). This scale proved adequate psychometric properties (Sánchez-Rosas \& Takaya, 2014). In the present study, unidimensionality and internal consistency were tested, and acceptable results were obtained ( $\mathrm{KMO}=0.74,82 \%$ variance accounted and factor loading $>0.50)$.

\section{Procedure}

The items were averaged within each scale to create overall indices of all variables. A correlational-explicative design was developed (Montero \& León, 2007). A protocol was formulated comprising instruments. The protocol was administered to the sample in regular classes of five different teachers during the first semester of the academic year. All participants 
were informed about the study objectives, and confidential data processing was guaranteed. Students voluntarily agreed to participate. Instructions were read aloud to students and it took thirty minutes to complete the administration.

\section{Data analysis}

To address the research questions, in addition to bivariate correlation procedures, using multivariate analysis such as path analysis is required. Path analysis is a method to evaluate the fit of causal models and to identify the direct and indirect contribution made by a set of independent variables to explain the variability of dependent variables (Pérez, Medrano, \& Sánchez-Rosas, 2013). Suggestions of Pérez et al. (2013) in order to interpret the fit indexes, direct, indirect effects, and significant path coefficients were followed. Several different indices were used to evaluate model fit to the data (Hu \& Bentler, 1995): chi-square degree of freedom ratio ( $\chi 2 / \mathrm{df})$, comparative fit index (CFI), goodness fit index (GFI), incremental fit index (IFI), and root-mean square error of approximation (RMSEA). The following criteria were used to evaluate the adequacy of model fit: $\chi 2 / d f \leq 2.0$ (Hair, Anderson, Tatham, \& Black, 1995), CFI $\geq 0.90$, GFI $\geq 0.90$, IFI $\geq 0.90$, and RMSEA $\leq 0.08$ (Browne \& Cudeck, 1993).

IBM SPSs Amos 19 (Arbuckle, 2010) software was used to conduct the statistical analysis according to proposed objectives.

\section{Results}

\section{Descriptive statistics}

Table 1 shows the means, standard deviations, correlations and internal consistency of the variables evaluated in this study. The correlations among the variables in this study were consistent with expectations regarding relationships among students' perceptions of the academic social environment (see table 1).

\section{Hypothesized model results}

In an initial test of the model, a partially acceptable fit to the data was obtained $\left[\chi^{2}(7, N=185)=33.06\right.$, $p=0.001, \chi^{2} / d f=4.72, \mathrm{CFI}=0.89, \mathrm{GFI}=0.95$, RMSEA $=0.142]$.
Table 1

Descriptive statistics and bivariate correlations

\begin{tabular}{lcccccc}
\hline & $\mathbf{1}$ & $\mathbf{2}$ & $\mathbf{3}$ & $\mathbf{4}$ & $\mathbf{5}$ & $\mathbf{6}$ \\
\hline $\begin{array}{l}\text { 1. Academic social } \\
\text { participation }\end{array}$ & 0.89 & & & & & \\
$\begin{array}{l}\text { 2. Perceived teacher } \\
\text { behavior }\end{array}$ & -0.08 & 0.83 & & & & \\
$\begin{array}{l}\text { 3. Task value } \\
\text { 4. Academic }\end{array}$ & -0.04 & $0.42^{* *}$ & 0.87 & & & \\
$\quad$ self-efficacy & $0.23^{* *}$ & $0.18^{*}$ & 0.10 & 0.93 & & \\
$\begin{array}{l}\text { 5. Enjoyment } \\
\text { 6. Shame }\end{array}$ & $0.26^{* *}$ & $0.45^{* *}$ & $0.62^{* *}$ & $0.17^{*}$ & 0.87 & \\
\hline M & $0.45^{* *}$ & 0.08 & $0.15^{*}$ & $-0.33^{*}$ & 0.05 & 0.88 \\
SD & 2.52 & 4.21 & 4.00 & 7.41 & 1.96 & 3.22 \\
\hline & 0.91 & 0.43 & 0.64 & 1.48 & 0.79 & 0.61 \\
\hline
\end{tabular}

Note. $N=185, \mathrm{M}=$ mean, $\mathrm{SD}=$ standard deviation. ${ }^{*} p<0.05$, ${ }^{* *} p<0.01$. Cronbach's alphas are on the diagonal. Compiled by the authors.

Modification indices suggested correlating perceived teacher behavior and class enjoyment, which made sense both theoretically and empirically. In this study, measurement of teacher behavior includes behaviors of teacher enthusiasm (Babad, 2007), for example, gestures, eye contact, movement during the class lecture, using humor and examples from real life. These behaviors would directly impact on emotions by the so-called emotional contagion. It has been shown that teacher's humor leads to students' enjoyment (Frenzel, Goetz, Lüdtke, Pekrun, \& Sutton, 2009; Goetz et al., 2006; Hatfield, Cacioppo, \& Rapson, 1994; Mottet \& Beebe, 2002). Additionally, the modification indexes also suggested a relationship between task value and academic social participation. As mentioned, task value serves to encourage engagement of students in academic activities (Eccles, 1987; Eccles et al., 1983; Wigfield \& Eccles, 2000), so it might be expected that task value has an impact on the activation of academic social participation.

Accordingly, the model was re-specified and evaluated by adding a direct effect from perceived teacher behavior on class enjoyment, and from task value on academic social participation. The revised model showed good fit to the data $\left[\chi^{2}(24, N=185)=\right.$ $11.72, p=0.068, \chi^{2} / d f=1.95$, CFI $=0.98$, GFI $=0.98$, RMSEA $=0.072]$ and explained $31 \%$ of variance of academic social participation. All path coefficients were significant, except for the path from self-efficacy to class enjoyment, which was marginally significant but in the predicted direction. Figure 2 displays the 
re-pecified model of academic social participation, with resulting path coefficients after adding these two new paths.

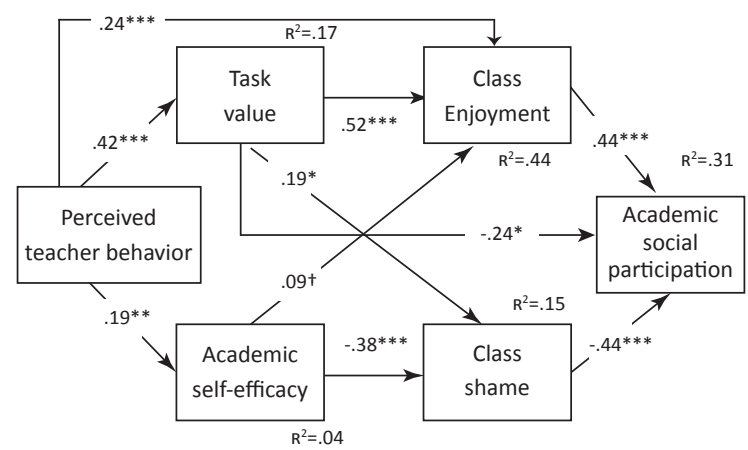

Figure 2. Re-specified model of academic social participation. ${ }^{\dagger} p<0.10,{ }^{\star} p<0.05,{ }^{* *} p<0.01,{ }^{* *} p<0.001 . R^{2}=$ explained variance. Compiled by the authors.

As suggested by Edwards and Lambert (2007) not only direct relations, but also indirect and total effects between the variables of a path model should be analyzed. Table 2 shows the decomposition of different standardized effects. Perceived teacher behavior and task value showed a strong overall effect on enjoyment, while academic self-efficacy had an important negative influence on shame. Furthermore, enjoyment and shame where the stronger predictors of academic social participation (see table 2).

\section{Discussion}

According to Christenson et al. (2012), engaged students do more than attend or perform academically; they also put forth effort, persist, self-regulate their behavior toward goals, challenge themselves to exceed, and enjoy challenges and learning. Student engagement is typically associated to desired social, emotional and academic learning outcomes. Also, engagement is a multidimensional construct that calls for an understanding about affective links between academic environment and student's active behavior. Moreover, engagement is not conceptualized as a student's trait, but as a state, which is highly influenced by school, family and peers ability to provide consistent expectations and learning support. Taking that into consideration, this study attempted to analyze effects and explanatory contribution of perceived teacher behavior, task value, self-efficacy, and class enjoyment and shame on academic social participation as a form of student engagement.

Based on the reviewed literature, we hypothesized: 1) a positive effect of teacher behavior on task value and self-efficacy and, after an additional specification, enjoyment; 2) a positive effect of task value and self-efficacy on enjoyment and a negative effect on shame; 3) a positive effect of enjoyment on academic social participation and a negative effect of shame on academic social participation and, after an

Table 2

Standardized effects of the model of academic social participation

\begin{tabular}{|c|c|c|c|c|}
\hline Predictor & Criterion & Direct effect & Indirect effect & Total effect \\
\hline Perceived teacher behavior & Task value & $0.42^{* * *}$ & - & $0.42^{* * *}$ \\
\hline Perceived teacher behavior & Academic self-efficacy & $0.19^{* *}$ & - & $0.19^{* *}$ \\
\hline Perceived teacher behavior & \multirow{3}{*}{ Enjoyment } & $0.24^{\star * *}$ & $0.23^{\star * *}$ & $0.47^{* * *}$ \\
\hline Task value & & $0.52^{* * *}$ & - & $0.52^{* * *}$ \\
\hline Academic self-efficacy & & 0.09 & - & 0.09 \\
\hline Perceived teacher behavior & \multirow{3}{*}{ Shame } & - & 0.01 & 0.01 \\
\hline Task value & & $0.19^{* *}$ & - & $0.19^{* *}$ \\
\hline Academic self-efficacy & & $-0.35^{\star * *}$ & - & $-0.35^{\star \star \star}$ \\
\hline Perceived teacher behavior & \multirow{5}{*}{$\begin{array}{l}\text { Academic } \\
\text { social } \\
\text { participation }\end{array}$} & - & $0.09^{*}$ & $0.09^{*}$ \\
\hline Task value & & $-0.24^{* *}$ & $0.15^{* *}$ & $-0.10^{\star *}$ \\
\hline Academic self-efficacy & & - & $0.18^{* *}$ & $0.18^{* *}$ \\
\hline Enjoyment & & $0.44^{* * *}$ & - & $0.44^{* * *}$ \\
\hline Shame & & $-0.43^{\star * *}$ & - & $-0.43^{\star * *}$ \\
\hline
\end{tabular}

Note. $N=185 . \dagger p<0.10,{ }^{*} p<0.05,{ }^{* *} p<0.01,{ }^{* *} p<0.001$. Compiled by the authors. 
additional specification, an effect of task value on academic social participation. This hypothesized model showed a good fit to the data and explained $31 \%$ of variance of academic social participation.

\section{Direct, indirect and total effects of the evaluated model}

\author{
Direct effects of perceived teacher behavior on \\ task value, academic self-efficacy and enjoy- \\ ment
}

Perceived teacher behavior's effects on task value $(\beta=0.42)$ and academic self-efficacy $(\beta=0.19)$ turned out as expected according to the hypothesized model. These results are in line with previous works suggesting that positive relationships with teachers promote students' development of self-efficacy and higher levels of task value (Ahmed et al., 2010; Smart, 2014; Velez \& Cano, 2012; Wang \& Eccles, 2013).

Furthermore, after model re-specification, a direct effect of perceived teacher behavior on class enjoyment was verified $(\beta=0.24)$. This effect could be explained by the emotional contagion phenomenon, in other words, the fact that teachers' enthusiasm and humor can be conveyed to students, increasing enjoyment of learning situations (Frenzel et al., 2009; Goetz et al., 2006; Hatfield et al., 1994; Mottet \& Beebe, 2002).

Therefore, students' confidence in their ability to carry out academic tasks, as well as the value they give to class activities, increase as their teacher shows behaviors such as carefully listening to students, answering questions, giving examples and using updated knowledge in lessons. Additionally, teacher's enthusiastic behavior helps students experience class as a pleasant situation.

\section{Effects of self-efficacy and task value on enjoyment and shame}

Firstly, academic self-efficacy relations with class enjoyment and shame were in predicted direction. Selfefficacy's negative effect on class shame $(\beta=-0.35)$ confirms that students that find themselves in control of class activities tend to feel less shame.

Secondly, and as expected, task value demonstrated a positive effect on class enjoyment, supporting the prediction that when students find class activities useful, interesting or important, they also experience them as more pleasant (Ainley \& Ainley, 2011; Noteborn et al., 2012; Pekrun et al., 2011; Putwain, Sander, \& Larkin, 2013; Sánchez-Rosas, n.d.). The relationship between task value and class shame was weak and opposite to the predicted direction. In this respect, it could be interpreted that even if a negative relation is to be expected between value assigned to a task and negative emotions regarding it; the fact that a task is valuable for a student may increase the emotional cost of failing in it. This would explain how a student that positively values a task could experience shame about it to some degree.

\section{Direct effects of task value, enjoyment and sha- me on academic social participation}

Effects obtained for class enjoyment and shame fit the hypothesized model. That is to say, class enjoyment had a positive effect on academic social participation $(\beta=0.44)$, while class shame had a negative effect of similar magnitude $(\beta=-0.43)$. This is consistent with recent literature, that has identified that positive emotions instigate students' engaged, approach oriented behaviors (Ainley \& Ainley, 2011; King et al., 2015; Pekrun, 2006; Pekrun \& LinnenbrinkGarcia, 2012); and negative emotions lead to rigid behavioral repertoires, discouraging effort, participation and help seeking (Ainley \& Ainley, 2011; King et al., 2015; Pekrun \& Linnenbrink-Garcia, 2012; Sánchez-Rosas, 2013; Sánchez-Rosas, Becco, \& Márquez, 2011). Therefore, when students enjoy class it is more likely that they feel encouraged to participate in social ways, such as asking questions, or involving themselves in class discussions. Conversely, if they feel shame, they will more likely avoid those behaviors.

On the other hand, after re-specifying the model, task value was found to produce a negative effect on academic social participation. Previously, it has been suggested that task value contributes to student engagement in learning activities (Cole, Bergin, \& Whittaker, 2008; Greene et al., 2004). Hence, including academic social participation as a form of student behavioral engagement, it would be expected that it related positively to task value. Nonetheless, behavioral engagement has often been defined by behaviors like persistence (Elliot \& Dweck, 1988) or effort regulation (Pintrich et al., 1993), which is closer to attention focusing and on-task permanence. It could be that, when a task is perceived as valuable or useful, students avoid behaviors such as asking 
questions or getting involved in discussions, with the purpose of fully focusing on the task.

These results highlight the importance of further research on diverse types of behavior comprised in behavioral engagement; and the assessment of relations between them and with other variables.

Indirect and total effects of perceived teacher behavior, task value and self-efficacy on achievement emotions and academic social participation

According to control-value theory of achievement emotions, contextual variables might indirectly impact on achievement emotions and its consequences, by affecting control and value appraisals (Pekrun et al., 2007). In this regard, an indirect positive influence was verified from perceived teacher behavior on class enjoyment ( $\beta=0.23$ ), which can be added to the direct influence of this variable to class enjoyment, with an overall positive effect $(\beta=0.47)$. Hence, when teachers attentively listen to their students and answer their questions, use up to date knowledge and give examples, not only do they increase enjoyment in a direct way, but they also make it easier for students to experience it as pleasant because of it being a valued activity.

Self-efficacy showed an indirect positive influence on academic social participation, supporting an assumption that perceiving a situation as under their control allows students to enjoy activities more, and feel less shame, therefore finding themselves with more motivation to participate (Putwain, Sander, \& Larkin, 2013). On the other hand, task value had, as indicated above, a direct negative effect on academic social participation, and at the same time, an indirect positive effect, although it was weaker $(\beta=0.15)$. The positive effect was mediated by class enjoyment and shame. This result presents the need for a deeper inquiry on the relationship between task value and academic social participation, as it appears to respond to a complex logic.

Perceived teacher behavior's indirect and total effect on academic social participation was weak and positive $(\beta=0.09)$, while bivariate correlation between these variables was also weak and in the opposite direction. This result could be considered as pointing out the importance of individual factors in moderating the relationship between context and engagement, as students with higher motivation may enjoy more classes with engaging teachers and take this chance to participate, while students with lower levels of self-efficacy and task value may dislike engaging teachers, therefore not feeling compelled to participate.

\section{Scope and limitations}

As a whole, results obtained in this study represent an advance as well as a challenge in student engagement research. More specifically, its purpose was to suggest academic social participation as one dimension pertaining student behavioral engagement. However, on this occasion, assessment of academic social participation comprised only a limited number of behaviors (e.g, Express an opinion on a topic that is being explained, Actively participate in class discussions, Ask the teacher questions to understand better).

Academic social participation can be conceived to include more diverse behaviors that can even be particular dimensions proper to this construct: academic help seeking, voluntary contributions, critical thinking, work with peers, and suggestions to the teacher. Academic help seeking consists in asking peers or teachers for help when other strategies turn out to be inefficient for understanding learning material or fulfilling a task (Sánchez-Rosas \& Pérez, 2015). Voluntary contribution relates to voluntary class participation that involves an exchange with the class as a whole, and requires the student's own initiative (Reeve, 2012). Critical thinking comprises, as the previous dimension, behaviors that imply sharing opinions with the class as a whole, particularly those expressing that student analyzed and adopted a stance regarding material or topics being discussed (Yazzie-Mintz \& McCormick 2012). About work with peers, it refers to participation behaviors involving interaction with one or more peers during class, spontaneously emerged among students (Reeve, 2012). Suggestions to the teacher involve students' voluntary intervention to request or communicate something to the teacher, as a means to personalize or improve the contents they are learning as well as the ways in which learning takes place (Reeve, 2012; Reeve \& Tseng, 2011).

As can be seen, academic social participation could integrate constructs that are usually considered in discrete ways by other conceptual frameworks. Consequently, further research should focus on delimiting the scope of this construct and its hereby-suggested dimensions, and at the same time it should advance in developing an instrument allowing to validly and reliably assess academic social participation. 
On the other hand, although most of the identified relationships appeared to be consistent with theoretically based hypotheses, some of them require to be more extensively addressed. For example, task value showed an unexpected effect on academic social participation. It can be thought that, due to measuring task value as a uni-dimensional variable, its components could have overlapped or canceled with each other. Some studies have, indeed, shown that the cost component, which reflects negative consequences of engaging an activity, has negative effects on some learning outcomes (for a review, see Barron \& Hulleman, 2015).

Finally, it is important to highlight perceived teacher behavior's direct and indirect effect on the remaining predicting variables that are considered of importance in explaining academic social participation. The effect on class enjoyment, which is a direct predictor of academic social participation, is to be emphasized. This suggests that special attention should be given to teacher behavior when planning interventions to enhance learning processes and their outcomes.

\section{References}

Ahmed, W., Minnaert, A., van der Werf, G., \& Kuyper, H. (2010). Perceived Social Support and Early Adolescents' Achievement: The Mediational Roles of Motivational Beliefs and Emotions. Journal of Youth and Adolescence, 39(1), 36-46. doi: 10.1007/s10964-0089367-7

Ainley, M., \& Ainley, J. (2011). Student engagement with science in early adolescence: The contribution of enjoyment to students' continuing interest in learning about science. Contemporary Educational Psychology, 36(1), 4-12. doi: 10.1016/j.cedpsych.2010.08.001

Arbuckle, J. L. (2010). Amos (Version 19.0). [Computer Program]. Chicago: SPSS.

Ashby, F. G., Isen, A. M., \& Turken, A. U. (1999). A neuropsychological theory of positive affect and its influence on cognition. Psychological Review, 106(3), 529-550. doi: 10.1037/0033-295x.106.3.529

Assor, A., Kaplan, H., \& Roth, G. (2002). Choice is good, but relevance is excellent: autonomy- enhancing and suppressing teacher behaviors predicting students' engagement in schoolwork. British Journal of Educational Psychology, 72(2), 261-278. doi: $10.1348 / 000709902158883$
Azevedo, F. S., di Sessa, A. A., \& Sherin, B. L. (2012). An evolving framework for describing student engagement in classroom activities. Journal of Mathematical Behavior, 31(2), 270-289. doi: 10.1016/j.jmathb.2011.12.003

Babad, E. (2007). Teachers' Nonverbal Behavior and its Effects on Students. In R. Perry \& J. Smart (Eds.), The Scholarship of Teaching and Learning in Higher Education: An Evidence-Based Perspective (pp. 201-261). The Netherlands: Springer. doi: 10.1007/1-4020-5742-3_7

Bandura, A. (1977). Self-efficacy: Toward a unifying theory of behavioral change. Psychological Review, 84(2), 191 215. doi: 10.1037/0033-295x.84.2.191

Bandura, A. (1986). Social foundations of thought and action: A social cognitive theory. Englewood Cliffs, NJ: Prentice-Hall.

Bandura, A. (1997). Self-efficacy: The exercise of control. New York: Freeman. doi: 10.5860/choice.35-1826

Barron, K. E., \& Hulleman, C. S. (2015). Expectancy-Value-Cost Model of Motivation. In N. Smelser \& P. Baltes (Eds.), International Encyclopedia of the Social \& Behavioral Sciences (pp. 503-509). United States: Pergamon. doi: 10.1016/b978-0-08-097086-8.26099-6

Browne, M. W., \& Cudeck, R. (1993). Alternative ways of assessing model fit. In K. A. Bollen \& J. S. Long (Eds.), Testing structural equation models (pp. 136-162). Beverly Hills, cA: Sage.

Christenson, S. L., Reschly, A. L., \& Wylie, C. (Eds.). (2012). Handbook of Research on Student Engagement. London: Springer. doi: 10.1007/978-1-4614-2018-7

Cole, J. S., Bergin, D. A., \& Whittaker, T. A. (2008). Predicting student achievement for low stakes tests with effort and task value. Contemporary Educational Psychology, 33(4), 609-624. doi: 10.1016/j.cedpsych.2007.10.002

Eccles, J. S. (1987). Gender roles and women's achievement-related decisions. Psychology of Women Quarterly, 11(2), 135-172. doi: 10.1111/j.1471-6402.1987. tb00781.x

Eccles, J. S. (2005). Subjective task value and the Eccles et al. model of achievement-related choices. In A. J. Elliot \& C. S. Dweck (Eds.), Handbook of competence and motivation (pp. 105-121). New York, NY: Guilford Press.

Eccles, J. S., Adler, T. F., Futterman, R., Goff, S. B., Kaczala, C. M., Meece, J. L., \& Midgley, C. (1983). Expectancies, values and academic behaviors. In J. T. Spence (Ed.), Achievement and achievement motivation (pp. 75-146). San Francisco: W. H. Freeman. doi: 10.1006/ ceps. 1999.1015 
Edwards, J. R., \& Lambert, L. S. (2007). Methods for integrating moderation and mediation: A general analytical framework using moderated path analysis. Psychological Methods, 12, 1-22. doi: 10.1037/1082-989X.12.1.1

Elliott, E. S., \& Dweck, C. S. (1988). Goals: An approach to motivation and achievement. Journal of Personality and Social Psychology, 54(1), 5-12. doi:10.1037//00223514.54.1.5

Federici, R. A., \& Skaalvik, E. M. (2014). Student's perception of instrumental support and effort in mathematics: the mediating role of subjective task values. Social Psychology of Education, 17(3), 527-540. doi: 10.1007/ s11218-014-9264-8

Fredricks, J. A., Blumenfeld, P. C., \& Paris, A. H. (2004). School engagement: Potential of the concept, state of the evidence. Review of Educational Research, 74(1), 59-109. doi: 10.3102/00346543074001059

Frenzel, A. C., Goetz, T., Lüdtke, O., Pekrun, R., \& Sutton, R. E. (2009). Emotional transmission in the classroom: Exploring the relationship between teacher and student enjoyment. Journal of educational psychology, 101(3), 705-716. doi: 10.1037/a0014695

Goetz, T., Frenzel, A. C., Hall, N. C., \& Pekrun, R. (2008). Antecedents of academic emotions: Testing the internal/external frame of reference model for academic enjoyment. Contemporary Educational Psychology, 33(1), 9-33. doi: 10.1016/j.cedpsych.2006.12.002

Goetz, T., Hall, N. C., Frenzel, A. C., \& Pekrun, R. (2006). A hierarchical conceptualization of enjoyment in students. Learning and Instruction, 16(4), 323-338. doi: 10.1016/j.learninstruc.2006.07.004

Greene, B. A., Raymond, B. M., Miller, H., Crowson, M., Duke, B. L., \& Akey, K. L. (2004). Predicting high school students' cognitive engagement and achievement: contributions of classroom perceptions and motivation. Contemporary Educational Psychology, 29(4), 462-482. doi: 10.1016/j.cedpsych.2004.01.006

Green, J., Liem, G. A. D., Martin, A. J., Colmar, S., Marsh, H. W., \& McInerney, D. (2012). Academic motivation, self-concept, engagement, and performance in high school: Key processes from a longitudinal perspective. Journal of Adolescence, 35(5), 1111-1122. doi: 10.1016/j.adolescence.2012.02.016

Grolnick, W. S., Ryan, R. M., \& Deci, E. L. (1991). Inner resources for school achievement: motivational mediators of children's perceptions of their parents. Journal of Educational Psychology, 83(4), 508-517. doi: 10.1037/0022-0663.83.4.508.
Guthrie, J. T., Wigfield, A., \& You, W. (2012). Instructional contexts for engagement and achievement in reading. In S. L. Christenson, A. L. Reschly, \& C. Wylie (Eds.), Handbook of Research on Student Engagement (pp. 601-634). New York: Springer. doi: 10.1007/9781-4614-2018-7_29

Hair, J. F., Anderson, R. E., Tatham, R. L., \& Black, W. C. (1995). Multivariate data analysis: with readings. Englewoods Cliffs, New Jersey: Prentice-Hall.

Hatfield, E., Cacioppo, J. T., \& Rapson, R. L. (1994). Emotional contagion. New York, NY: Cambridge University Press.

Hijzen, D., Boekaerts, M., \& Vedder, P. (2007). Exploring the links between students' engagement in cooperative learning, their goal preferences and appraisals of instructional conditions in the classroom. Learning and Instruction, 17(6), 673-687. doi: 10.1016/j.learninstruc.2007.09.020

Hu, L. T., \& Bentler, P. M. (1995). Evaluating model fit. In R. Hoyle (Ed.), Structural equation modeling: Concepts, issues, and applications (pp. 76-99). Thousand Oaks, CA: Sage.

King, R. B., McInerney, D. M., Ganotice, F. A., \& Villarosa, J. B. (2015). Positive affect catalyzes academic engagement: cross-sectional, longitudinal, and experimental evidence. Learning and Individual Differences, 39, 6472. doi: 10.1016/j.lindif.2015.03.005

Lewis, M., \& Haviland-Jones, J. M. (Eds.) (2000). Handbook of Emotions. New York Guilford Press.

Liem, A. D., Lau, S., \& Nie, Y. (2008). The role of self-efficacy, task value, and achievement goals predicting learning strategies, task disengagement, peer relationship, and achievement outcome. Contemporary Educational Psychology, 33(4), 486-512. doi: 10.1016/j. cedpsych.2007.08.001

Linnenbrink-Garcia, L., Rogat, T. K., \& Koskey, K. L. K. (2011). Affect and engagement during small group instruction. Contemporary Educational Psychology, 36(1), 13-24. doi: 10.1016/j.cedpsych.2010.09.001

Linnenbrink-Garcia, L., Rogat, T. K., \& Koskey, K. L. K. (2011). Affect and engagement during small group instruction. Contemporary Educational Psychology, 36(1), 13-24. doi: 10.1016/j.cedpsych.2010.09.001

Montero, I., \& León, O. G. (2007). A guide for naming research studies in psychology. International Journal of Clinical and Health Psychology, 7(3), 847-862.

Mottet, T. P., \& Beebe, S. A. (2002). Relationships between teacher nonverbal immediacy, student emotional response, and perceived student learning. 
Communication Research Reports, 19(1), 77-88. doi: 10.1080/08824090209384834

Noteborn, G., Bohle Carbonell, K., Dailey-Herbert, A., \& Gijselaers, W. (2012). The role of emotions and task significance in virtual education. Internet and Higher Education, 15(3), 176-183. doi: 10.1016/j.iheduc.2012.03.002

Patrick, H., Ryan, A. M., \& Kaplan, A. (2007). Early Adolescents' Perceptions of the Classroom Social Environment, Motivational Beliefs, and Engagement. Journal of Behavioral Psychology, 99(1), 83-98. doi: 10.1037/0022-0663.99.1.83

Pekrun, R. (2006). The control-value theory of achievement emotions: Assumptions, corollaries and implications for educational research and practice. Educational Psychology Review, 18(4), 315-341. doi: 10.1007/s10648006-9029-9

Pekrun, R. (2007). Emotions students' scholastic development. In Schutz, P. A., \& R. Pekrun, Emotions in Education (pp. 553-610). San Diego, CA: Academic Press.

Pekrun, R., Elliot, A. J., \& Maier, M. A. (2006). Achievement goals and discrete achievement emotions: A theoretical model and prospective test. Journal of Educational Psychology, 98(3), 583-597. doi: 10.1037/00220663.98.3.583

Pekrun, R., Elliot, A. J., \& Maier, M. A. (2009). Achievement Goals and Achievement Emotions: Testing a Model of Their Joint Relations With Academic Performance. Journal of Educational Psychology, 101(1), 115-135. doi: $10.1037 / \mathrm{a} 0013383$

Pekrun, R., Frenzel, A., Goetz, T., \& Perry, R. P. (2007). The control-value theory of achievement emotions: An integrative approach to emotions in education. In P. A. Schutz \& R. Pekrun (Eds.), Emotion in education (pp. 13-36). San Diego, CA: Academic Press.

Pekrun, R., Goetz, T., Frenzel, A., Barchfeld, P., \& Perry, P. (2011). Measuring emotions in students' learning and performance: The Achievement Emotions Questionnaire (AEQ). Contemporary Educational Psychology, 36(1), 36-48. doi: 10.1016/j.cedpsych.2010.10.002

Pekrun, R., Goetz, T., Perry, R.P., Kramer, K., \& Hochstadt, M. (2004). Beyond test anxiety: Development and validation of the Test Emotions Questionnaire (TEQ). Anxiety, Stress and Coping, 17(3), 287-316. doi: 10.1080/10615800412331303847.

Pekrun, R., Goetz, T., Titz, W., \& Perry, R. P. (2002). Positive emotions in education. In E. Frydenberg (Ed.), Beyond coping: Meeting goals, visions, and challenges (pp. 149-174). Oxford, UK: Elsevier. doi: 10.1093/med:psych/9780198508144.001.0001

Pekrun, R., \&Linnenbrink-Garcia, L. (2012). Academic emotions and student engagement. In S. L. Christenson, A. L. Reschly, \& C. Wylie (Eds.). Handbook of Research on Student Engagement. New York: Springer. doi: 10.1007/978-1-4614-2018-7

Pérez, E., Medrano, L., \& Sánchez-Rosas, J. (2013). El path analysis: conceptos básicos y ejemplos de aplicación. Revista de la Asociación Argentina de Ciencias del Comportamiento, 5, 52-66.

Pintrich, P. R., Smith, D. A. F., Garcia, T., \& McKeachie, W. J. (1993). Reliability and predictive validity of the motivated strategies for learning questionnaire (MSLQ). Educational and Psychological Measurement, 53(3), 810-814. doi: 10.1177/0013164493053003024

Putwain, D., Sander, P., \& Larkin, D. (2013). Academic self-efficacy in study-related skills and behaviours: relations with learning-related emotions and academic success. British Journal of Educational Psychology, 83(4), 633-650. doi: 10.1111/j.2044-8279.2012.02084.x

Reeve, J. (2012). A self-determination theory perspective on student engagement. In S. L. Christenson, A. L. Reschly \& C. Wylie (Eds.), Handbook of Research on Student Engagement (pp. 149-172). New York: Springer. doi: 10.1007/978-1-4614-2018-7

Reeve, J. \& Tseng, C. (2011). Agency as a fourth aspect of students' engagement during learning activities. Contemporary Educational Psychology, 36(4), 257-267. doi: 10.1016/j.cedpsych.2011.05.002

Sánchez-Rosas, J. (2013). Búsqueda de Ayuda Académica, Autoeficacia Social Académica y Emociones de Logro en Clase en Estudiantes Universitarios. Revista Argentina de Ciencias del Comportamiento, 5, 35-41.

Sánchez-Rosas, J. (n. d.). The Achievement Emotions Questionnaire for Argentinean university students. In press. Evaluar.

Sánchez-Rosas, J., Becco, V., \& Marquez, F. (2011). ¿Cómo no voy a saber eso? Efectos y funciones de la vergüenza en clase. III Congreso Internacional de Investigación y Práctica Profesional en Psicología, XVIII Jornadas de Investigación, VII Encuentro de Investigadores en Psicología del Mercosur, UBA.

Sánchez-Rosas, J., \& Pérez, E. (2015). Measuring threats, benefits, emotional costs and avoidance of academic help seeking in Argentinian university students. Pensamiento Psicológico, 13(2), 49-64. doi: 10.11144/Javerianacali.PPSI13-2.mtbe 
Sánchez-Rosas, J., Piotti, A., Sánchez, V., Pereira, A., \& Debat, E. (2011). Implicancias del interés, la importancia y la utilidad de los materiales y contenidos de aprendizaje para las emociones académicas. Presented at the III Congreso de Psicología de la Facultad de Psicología de la Universidad Nacional de Córdoba, Argentina. doi: 10.13140/2.1.4317.9526

Sánchez-Rosas, J., \& Takaya, P. B. (2014). Desarrollo de dos escalas de compromiso comportamental de estudiantes en clase. Presented at the I Congreso Internacional de Psicología. IV Congreso de Psicología de la Facultad de Psicología de la Universidad Nacional de Córdoba, Argentina.

Schaufeli, W. B., Martínez, I. M., Pinto, A. M., Salanova, M., \& Bakker, A. B. (2002). Burnout and Engagement in University Students: A Cross-National Study. Journal of Cross-Cultural Psychology, 33(5), 464-481. doi: $10.1177 / 0022022102033005003$

Smart, J. B. (2014). A mixed methods study of the relationship between student perceptions of teacher-student interactions and motivation in middle level science. Research in Middle Level Education, 38(4), 1-19. doi: 10.1080/19404476.2014.11462117

Solberg, V. S., O’Brien, K., Villareal, P., Kennel, R. \& Davis, B. (1993). Self-efficacy and hispanic college students: Validation of the College Self-Efficacy Instrument. Hispanic Journal of Behavioral Sciences, 15(1), 80-95. doi: 10.1177/07399863930151004

Sterba, S. K., \& Foster, E. M. (2008). Self-selected sample. In Encyclopedia of Survey Research Methods (pp. 806808). Thousand Oaks, California: Sage Publications.

Takaya, P. B. (2014). Compromiso comportamental en clase de estudiantes de Psicología Clínica de la Facultad de Psicología de la U.N.C.: Contribución explicativa de variables motivacionales y emocionales. Unpublished final investigation report, Universidad Nacional de Córdoba, Licenciatura en Psicología.

Takaya, P. B., \& Sánchez-Rosas, J. (2014). Desarrollo de una escala para evaluar la promoción docente del compromiso comportamental de estudiantes en clase. Presented at the I Congreso Internacional de Psicología. Iv Congreso de Psicología de la Facultad de Psicología de la Universidad Nacional de Córdoba.

Vélez, J. J., \& Cano, J. (2012). Instructor verbal and nonverbal immediacy and the relationship with student self-efficacy and task value motivation. Journal of Agricultural Education, 53(2), 87-98. doi: 10.5032/jae.2012.02087

Wang, M. T., \& Eccles, J. S. (2013). School context, achievement motivation, and academic engagement: A longitudinal study of school engagement using a multidimensional perspective. Learning and Instruction, 28, 13-23. doi: 10.1016/j.learninstruc.2013.04.002

Wigfield, A., \& Eccles, J. S. (1992). The development of achievement task values: A theoretical analysis. Developmental Review, 12(3), 265-310. doi: 10.1016/02732297(92)90011-p_

Wigfield, A., \& Eccles, J. S. (2000). Expectancy-value theory of achievement motivation. Contemporary Educational Psychology, 25(1), 68-81. doi: 10.1006/ceps.1999.1015

Yazzie-Mintz, E., \& McCormick, K. (2012). Finding the humanity in the data: understanding, measuring, and strengthening student engagement. In S. L. Christenson, A. L. Reschly \& C. Wylie (Eds.), Handbook of Research on Student Engagement (pp. 743-761). New York: Springer. doi: 10.1007/978-1-4614-2018-7 